\title{
Entrepreneurship and the Relation with Mission in the Church of Indonesia
}

\author{
Peter Dekkerl)* \\ 1) Hogeschool Windesheim, Netherlands \\ *Correspondence author: peter@pamakassar.nl
}

Received: 31 January 2020/Revised: 06 September 2020/Accepted: 18 October 2020

\begin{abstract}
How important is Entrepreneurship in the context of the church of Indonesia? A sketch of the common situation and a desirable situation. How can the church grow when there is still a paradox about the relation between: "Entrepreneurship and the church"? What could be the future for the church in a rapidly changing Indonesia? In this article the author wants to describe the current status of the church in Indonesia. The author also wants to discuss the rise of Islam in Indonesia. Finally, the author wants to develop a model that will help Christians gain recognition in areas that not have been reached with the gospel in Indonesia today. The author will do this on the basis of his experiences in recent years when working in Indonesia to establish bridges between Christians and Muslims in an area that has not yet been reached. The author did this by setting up and starting up activities that give Christians a legitimate status in that area. From this legitimate status arise relationships and contacts with the local population. The focus of this article is on his experiences. The church is experiencing major difficulties in Indonesia in and after 2020. How can the church in Indonesia go out and reach people who do not yet know Jesus as their Savior and Lord?
\end{abstract}

Keywords: Church, Entrepreneurship, Mission.

\begin{abstract}
Abstrak
Seberapa pentingkah Entrepreneurship di dalam konteks gereja Indonesia? Satu satunya sketsa situasi umum dan situasi yang diinginkan. Bagaimana gereja bisa tumbuh ketika masih ada paradoks tentang hubungan antara: "Entrepreneurship dan gereja"? Apa yang bisa menjadi masa depan bagi gereja di Indonesia yang berubah dengan cepat? Dalam artikel ini penulis ingin menggambarkan status gereja saat ini di Indonesia. Penulis juga ingin membahas kebangkitan Islam di Indonesia. Akhirnya, penulis ingin mengembangkan model yang akan membantu orang Kristen mendapatkan pengakuan di bidang-bidang yang belum terjangkau oleh Injil di Indonesia saat ini. Penulis akan melakukan ini berdasarkan pengalamannya dalam beberapa tahun terakhir ketika bekerja di Indonesia untuk membangun jembatan antara Kristen dan Muslim di daerah yang belum tercapai. Penulis melakukan ini dengan mendirikan dan memulai kegiatan yang memberi orang Kristen status
\end{abstract}


yang sah di bidang itu. Dari status yang sah ini timbul hubungan dan kontak dengan penduduk setempat. Fokus artikel ini adalah pada pengalamannya. Gereja mengalami kesulitan besar di Indonesia pada dan setelah tahun 2020. Bagaimana gereja di Indonesia dapat pergi dan menjangkau orang-orang yang belum mengenal Yesus sebagai Juruselamat dan Tuhan mereka?

Kata-kata Kunci: Entrepreneurship, Gereja, Misi.

\section{Introduction}

The author has lived and worked in Indonesia for some years. His most important task is to connect Christians and people of different faiths in this country. The author does not do this by evangelizing or by starting a church. Instead he encourages students of theological schools and leaders of Indonesian churches to look outside the church doors with the help of Social Entrepreneurship. ${ }^{.}$Social entrepreneurship will help to develop religious entrepreneurship. ${ }^{2}$ This means in the future, to start new faith communities with students and church-leaders. This is often driven by a desire to expand faith communities and to widen their networks into new constituencies. ${ }^{3}$ These forms of religious entrepreneurship often have social and civic dimensions that compare well with similar activities by social entrepreneurs. Yet, religious entrepreneurship is only noticed and studied in limited ways within the field of social entrepreneurship. Definitions of social entrepreneurship vary significantly, ${ }^{4}$ but the driving factor is often considered to be a social vision. The inspiration and motivation for that vision may have multiple sources: humanitarian, political, medical, academic, ${ }^{5}$ religious ${ }^{6}$

${ }^{1}$ In the wide context, world is still struggling with COVID-19; even business and entrepreneurship is become hard. Zahra discussed it in his journal, how

entrepreneurship post Covid era. Shaker A. Zahra, "International Entrepreneurship in the Post Covid World," Journal of World Business (2020),

https://doi.org/10.1016/j.jwb.2020.101143.

2 Austin, Stevenson and Wei-Skillern devided enrepreneurship into two types: social entrepreneurship and commercial entrepreneurship. James Austin, Howard Stevenson, and Jane Wei-Skillern, "Social and Commercial Entrepreneurship: Same, Different or Both?," SAGE Journal: Entrepreneurship Theory and Practice 30, no. 1 (2006), https://doi.org/10.11ll/j.1540-6520.2006.00107.x in S. Trevsi Certo and Toyah Miller, "Social Entrepreneurship: Key Issues and Concepts," Business Horizons 51 (2008): 268, https://doi.org/10.1016/j.bushor.2008.02.009.

${ }^{3}$ P. Ward, Liquid Ecclesiology: The Gospel And The Church (Leiden: Brill, 2017), 108.

${ }^{4}$ J. R. Mair, Social Entrepreneurship (Basingstoke: Palgrave Macmillan, 2006).

${ }^{5}$ Chiara Marzocchi, Fumi Kitagawa, Mabel Sanchez-Barrioluengo, "Evolving Missions and University Entrepreneurship: Academic Spin-Off and Graduate Start-ups 
and more. Even, Marshall tries to see the impact of entrepreneurship in the rural church. Despite the suspicious view of some church leaders about "business", actually entrepreneurship does give good impact to rural church. ${ }^{7}$ Munoz and Kimmitt said that social entrepreneurship is a part of social mission. ${ }^{8}$ Austin, Stevenson and Wei-Skillern said that this program is increasing in nonprofit organization in several decades. ${ }^{9}$ It has a deep foundation in the command of Jesus to "love your neighbor as yourself" (Matthew 22:39).

Together with students we strongly focus on areas where there are no churches but where (some) Christians live and work. Students are challenged to go to areas that have not been or have hardly been reached instead of going back to the church in which they grew up. Students are not out to compete with existing churches, every church needs new workers, but they have to focus on those places where the church is not given permission to exist. Development workers must recognize that their allegiance to God goes beyond all the tribal rivalries of families, religious institutions, politics, and national loyalties. ${ }^{10}$

This focus causes quite a few problems:

1. It is hard to access these places because of lack of home bases or churches.

2. There is no legitimate status to be active in a village or town that holds a different belief system.

3. Students and pastors are often bound by agreement with their home church. Their home church sponsored their studies and after they graduate, they have to go back to their home church to work there.

in the Entrepreneurial Society," The Journal of Technology Transfer 44 (2019): 167, https://link.springer.com/content/pdf/10.1007/s10961-017-9619-3.pdf.

${ }^{6}$ Dodd and Gotsis argue that religion and entrepreneurship have a correlation.

In their journal, one of their conclusion is religion give impact to entrepreneurial process. Sarah Drakopoulou Dodd and George Gotsis, "The Interrelationships between Entrepreneurship and Religion," The International Journal of Entrepreneurship and Innovation 8, no. 2 (2007): 101, https://doi.org/10.5367/000000007780808066.

7 Jerry Marshall, "Is Rural Enterprise God's Business?," Rural Theology 14, no. 2

(November 2016): 82, https://doi.org/10.1080/14704994.2016.1234852.

${ }^{8}$ Pablo Munoz and Jonathan Kimmit, "Social Mission as Competitive

Advantage: A Configurational Analysis of the Strategic Condition of Social

Entrepreneurship," Journal of Businness Research 101(2019): 426,

https://doi.org/10.1016/j.jbusres.2019.02.004.

${ }_{9}^{9}$ James Austin, Howard Stevenson, and Jane Wei-Skillern, "Social and Commercial Entrepreneurship: Same, Different or Both?," SAGE Journal: Entrepreneurship Theory and Practice 30, no. 1 (2006): 1, https://doi.org/10.1111/j.1540-6520.2006.00107.x.

${ }^{10}$ S. Bailey, Biblical Wholism (Colorado Springs: Cama Services, 2019), 97-106. 
Beside that pastors don't want to leave their home church because of family relations.

Based on a practical case study the author wants to show there are options to overcome these problems. He hopes and prays that the reader will be encouraged to follow this way of mission. The author starts with a demographic and a small geographical exploration, continue with the rise of Islam in Indonesia and then the author will develop the practical example into a working model. He will conclude with discussing the workability of this model and as an appendix recommendations for the Indonesian church and mission organizations.

\section{Theory}

\section{Demographic Exploration}

Indonesia is the country with the most Muslim believers in the world. Approximately $87.2 \%$ of all inhabitants claim Islam as their religion, approximately 207 million inhabitants. The second major religion in Indonesia is Christianity. According to the Indonesian government, approximately $6.9 \%$ of all residents are Christians. In addition, $2.9 \%$ are Catholic. Together that is almost $10 \%$ of the population, just under 24 million people. It is unclear how many Christians are part of an underground church and not count in this numbers. Furthermore, there are three other recognized religious groups in Indonesia: Hinduism (1.7\%), Buddhism (0.7\%), and Confucianism $(0.05 \%) .{ }^{11}$ The followers of other religions are negligible (around $0.5 \%$ ). Striking is that there are no Atheists. This is in contrast to the Western world, where we see an ever-increasing growth in the number of people without a religious belief.

This article focuses on the Gereja Kemah Injil Indonesia-church of Indonesia. ${ }^{12}$ It is hard to find out how the Gereja Kemah Injil Indonesiachurch grows in Indonesia. Some conclusions can be made about the graphic shown below about the number of children receiving a Christian education, but this is outside the focus and goal of this article and demands further demographical research about the development of Christian belief in Indonesia.

\footnotetext{
11 "Portal Informasi Indonesia: Profil - Agama," https://www.indonesia.go.id/profil/agama.

${ }^{12}$ Gereja Kemah Injil Indonesia-church of Indonesia.
} 


\section{Geographical}

We can divide Indonesia in reached and unreached areas. Unreached area means people who have never had the opportunity to hear about the Gospel of Jesus Christ. In a reached area people have the opportunity to hear about the Gospel of Jesus Christ by visiting visible churches or following Christian education. How can we explain the word "reached area"? In this article, the author defines it like this: A reached area is an area where is a manifestation of God's ideals, principles, values and will. ${ }^{13}$

One of the most important benchmarks of unreached areas is: whether or not there is a local church within an hour's travel from where someone lives. To travel more than one hour is a hard task in Indonesia. The traffic can be challenging in small or big cities and many places in Indonesia do not have good roads.

\section{Islam Belief of Indonesia}

Major belief in Indonesia is Islam. Around $87,2 \%$ of all inhabitants has an Indonesian identity with Islam belief written in it. More and more it looks like Islamic beliefs are growing and gaining power in Indonesia. ${ }^{14}$ "Islamization can be found in the deepening use of Islamic sources, the involvement of a greater number of Islamic organizations, the efforts toward more revivalist or conservative interpretations of certain practices, and the efforts to implement of zakat as an individual tax obligation to the state. Islamization is "a process of deepening commitment to standards of normative Islamic belief, practice and religious identity. Those standards are subject to contestation among groups and individuals." ${ }^{15}$ The influence of Islamization has also increased charitable activities within Salafi networks from the Middle

${ }^{13}$ M. L. Russell, The Missional Entrepreneur (Birmingham, Alabama, USA: New Hope Publishers, 2010), 47.

${ }^{14}$ A. Fauzia, "Islamic Philanthropy in Indonesia: Modernization, Islamization, and Social Justice," Austrian Journal of South-East Asian Studies 10, no. 2 (2017): 223-236, https://doi.org/10.14764/10.ASEAS-2017.2-6.

${ }^{15} \mathrm{M}$. Ricklefs, Islamisation and Its Opponents in Java: A Political, Social, Cultural and Religious History, c. 1930 to the Present (Singapore: National University of Singapore Press, 2012), 516. 
East to Indonesia. Indonesia is also seeing the rise of Islamic law in some part of West Indonesia. ${ }^{16}$

According to a recent survey, $70 \%$ of all Indonesian people see the introduction of Islamic law as a good alternative to the poverty and corruption which currently exist. ${ }^{17}$ What will be the role of the church in a future with Islamic law? Is it possible to stop this or will Christianity become an underground religion in Indonesia in the future ${ }^{18}$ What are the possibilities to reach out to others for the church in a country that talks about freedom of belief for everyone? ${ }^{19}$

We can describe "freedom of belief" as: The right of people to hold any religious beliefs, or none, and to carry out any practices in accordance with those beliefs or with that absence of belief, so long as these practices do not interfere with other people's legal or civil rights, or any reasonable laws, without fear of harm or prosecution. ${ }^{20}$

Lots of areas of Indonesia have hardly been reached with the gospel, and in other areas the influence of Christian belief is marginal. We see this even in "reached" areas. The author spoke some time ago with an Indonesian pastor. He said that in Central Indonesia a lot of villages don't have a church. Muslims are focusing on these areas and building mosques with a lot of money from Arabic countries. Local people become interested because people from outside are interested in them. A lot of people change their Christian beliefs and become Muslim. This is a warning to the reader and the church of Indonesia not to focus only on "unreached" areas.

The author thinks this is an important task for local churches near these villages to be present. Jesus commands us to go out and not to stay in a local church (Mark 16:15). In this article the author wants to focus on areas where the church has no influence because there are no churches. The author asks all readers of this article to look around: Everyone has people around them who have never heard the Gospel of

${ }^{16}$ Lina Kushidayati, "The Development of Islamic Law in Indonesia," शIJIS: Qudus International Journal of Islamic Studies 1, no. 2 (2013): 166,

https://journal.iainkudus.ac.id/index.php/QIJIS/article/view/185/192.

${ }_{17}$ Ibid., 163-177.

${ }^{18}$ R. Dagblad, "Reformatorisch Dagblad," https:/www.rd.nl/kerk-

religie/indonesië-sluit-twee-kerken-1.1587326.

${ }^{19}$ A. Fauzia: 223-236.

20 "Your Dictionary," s.v. "freedom-of-religion," https://www.yourdictionary.com/freedom-of-religion. 
Jesus. Please open the windows and the doors of the church to which you belong and look for all the lost sheep. There is still time, but we do not know how long. Believers should spend their short time on earth in a proper way to build the Kingdom of our Mighty God. Go out to tell the story of Jesus, His Kingdom has already begun.

\section{Method}

This research using qualitative research method. Writer using books and journal as primary resources. Alan Bryman said that one of the characteristic of qualitative research method (widely) is interpretivist. ${ }^{21}$ This research isn't focus in collecting and analyzing data. ${ }^{22}$

\section{Results and Discussion}

A good starting point is to check all schools in an area. Are their schools with Christian education? Indonesia has a website with a lot of information about schools. If we look at the number of Christian primary schools in Indonesia (Sekolah Dasar) we see that just over 9\% of all children attend a Christian school and $4 \%$ of all children attend a Catholic school..$^{23}$ That means that 3.2\% of all children with no Christian background are attending a Christian school; a remarkable difference compared to the number of inhabitants who are Christian or Catholic. If we look at secondary schools, we see even more differences.

For SMP (Sekolah Menengah Pertama, secondary education): 10\% of all students attend a Christian SMP, ${ }^{24}$ and 4,5 \% go to a Catholic school. For SMA (Sekolah Menengah Atas) $12 \%$ of all students attend a Christian SMA and 5,5\% go to a Catholic school. ${ }^{25}$ When we analyze vocational

${ }^{21}$ Alan Bryman, Social Research Methods, $4^{\text {th }}$ edition (New York: Oxford University Press, 2012), 380.

22 Ibid., 380.

23 "Publikasi Statistik - SD,"

http://publikasi.data.kemdikbud.go.id/uploadDir/isi_3939CAB9-7519-4743-817D451543C7CFBB_.pdf.

24 "Publikasi Statistik - SMP,"

http://publikasi.data.kemdikbud.go.id/uploadDir/isi_2D2BE4A7-1490-4240-8A30-

IFCCC29696B0_pdf.

25 "Publikasi Statistik - SMA,"

http://publikasi.data.kemdikbud.go.id/uploadDir/isi_AF06EEA9-768D-4A19-B2C9-

OC69E973DFBF_.pdf. 
high school at an SMK (Sekolah Menengah Kejujuran), however we can see only $6 \%$ go to a Christian school and 2,4\% Catholic school. ${ }^{26}$

The graphic below shows this phenomenon:

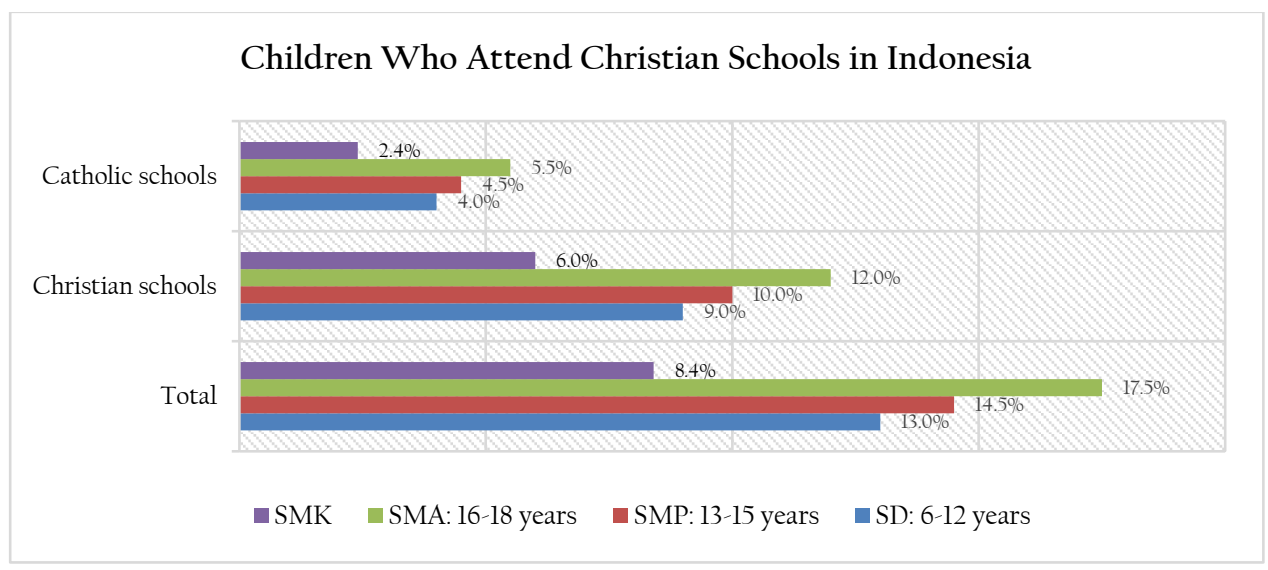

Figure 1. A graphical view of children who attend Christian School ${ }^{27}$

In the area where the author works, the total amount of Christians is a few dozen people. When the author asks their KTP (Kartu Tanda Penduduk, Indonesian official identity card), most of the time it says: "Islam" as their religious identity. It is not possible to live in these areas and work as a Pastor, Evangelist or as a Christian theology student. If you want to live in these areas to bring the gospel, you have to find another job to find a secure status. Moreover, to live there as a Christian of Christian family is very hard. Indonesia is a huge country and a lot of areas are very hard to reach geographically and this is a big obstacle to bring the Gospel. In these areas there is also a lack of education. In Indonesia you have to go to the school in the area which is written on the family card (Kartu Keluarga). Even if you have the money to send your children to the city (to receive a Christian education), you have to change the family card which is a process that takes about one year. If there are Christian schools, the area is reached. It is still important to send workers to areas which contains Christian education in schools,

26 "Publikasi Statistik - SMK,"

http://publikasi.data.kemdikbud.go.id/uploadDir/isi_02552295-057B-4347-BCB3-

71A2DIE2AEEC_.pdf.

27 This is a summary from data get from "Publikasi Statistik," http://publikasi.data.kemdikbud.go.id/index.php?thn=2019\&sek_id=\&bpid=\&pageNum $=2$. 
but this is outside the main goal of this article. This article wants to develop a model for reaching out to unreached areas. For all activities you need money and capable workers from the church. How is the condition and financial situation of the Indonesian church?

\section{Average Condition and Financial Situation of the Indonesian Church}

It is hard to find out the condition of the Indonesian church. On one side, the author has talked with mission organizations who declare that the church is: "weak and on the border of a financial abyss, a lot of pastors are not well educated and there is no vision". We can see the condition of the Indonesian church by the buildings many churches use for their church services. Many times, churches rent space in hotels, shops, or offices. They also use Christian schools to organize their celebrations and church meetings. They are totally invisible for the people outside. It looks like they have only small amount of money. A lot of pastors don't have a lot of education and to develop a vison for future is not easy in an Indonesian context.

On the other side, the strong side, the author has seen that in a disaster, such as happened in Palu, ${ }^{28}$ churches can mobilize and offer help and to give a lot of money. A lot of churches in Indonesia sent resources, workers and money for the victims and the rebuilding of Palu. When the need is high, there is still money and resources to provide for the emergency. But most of the time, workers and stuff are sent without any consultation or a plan of action.

This leads to a lot of mistakes and wasted money. It is important to spend time gathering facts and data, and from your findings, implement a plan of action. ${ }^{29}$ A lot of churches are starting to set up a department social for future disasters and social work. Theological schools are developing fast and a lot of pastors wants to follow more education, which is a very good point. It also looks like that vision changed; the Covid-19 pandemic helps the church a lot to develop a new vision. It looks like that the statement of the mission organizations is no longer a valuable statement.

If the author looks around where he lives in Central Indonesia a lot of churches are doing fine. They have their own buildings, enough money

\footnotetext{
28 "Indonesia Earthquake: Hundreds Dead in Palu Quake and Tsunami," https:/www.bbc.com/news/world-asia-45683630.

${ }^{29}$ Practitioners, Hands (Colorado Springs, USA: CAMA Services, 2019), 108.
} 
for salary and other things, and during the week there are a lot of activities. The minimum wage in Indonesia depends on the area where you are living. ${ }^{30}$ The highest wage is paid in Jakarta (3,9 Juta Rp., 270 USD a month), the lowest wage is paid in Central Java (1,6 Juta Rp., 105 USD a month). These amounts do not include the "1 $3^{\text {th }}$ month" wage. The wage or salary of a pastor is not very high, when we compare this with the minimum wage. On the first place it looks the wage of a pastor is around the minimum wage. Maybe it is enough to live, but it is by far not enough to do some extras such as: more education, to attend conferences or to go to Rakernas (Rapat Kerja Nasional), the regularly meeting of all Gereja Kemah Injil Indonesia pastors in an area. Rapat Kerja Nasional (church meeting in Indonesia) can be seen as a retreat, but it is also the place where important decisions are made about the church. Another factor is that many members of the church do not have enough money to live on in combination with the Biblical principle of "tithing". Many times, the author has heard stories of church members who give some part of the harvest of the land instead of money.

This makes the living of a pastor much harder. What can he do with this harvest? It is not possible to pay the rent of the church, to pay the wage of the pastor, or other things as electricity, taxes and maintenance of the building. If the church has lack of money, it also has lack of money for activities such as mission and, that is the most important thing, off being a church. God places believers in the world to share the Gospel and not to close the doors for the people outside of the church. How can the church get more resources to be successful in this mission? In this article the author will answer the question: "how can we get more entrances in a closed area?". What can "Entrepreneurship do for the mission of the church"?

\section{Most Desirable Situation in Indonesia}

The most eligible situation is a church in Indonesia who has the desire to go out to the people of Indonesia to reach them with the saving grace of the Gospel of Jesus Christ. This will not happen by setting up a celebration behind closed doors and windows on Sunday morning. To be clear, a celebration strengthens the mutual bond between church

30 "Salarissen En Minimumloon In Indonesië (2019),"

https://indearchipel.com/2018/12/07/minimumloon-indonesie-2019/. 
members, but is still limited to the people who have already joined a church as a church member. In the author's experience, he has not observed many churches being involved in activities in their communities. On the one hand, maybe this has to do with threats and hazards. Local people do not want to see activities from the churches. On the one hand, it would be good for the Indonesian church to set up plans for organizing more Christian activities. The church needs to start thinking: "How can we reach out to the people around these churches"? So many people do not know who Jesus is yet for them. It is also very important that a church collect money to be a healthy church, including a wage or salary for the pastor according to the rules of the synod of the church. They can also collect money for outreach to the people around them. How can a church earn more money for these activities so that there is more room in that community for outreach to different believers?

\section{Entrepreneurship Can Make Missions Possible}

Some readers know the expression "Business as mission", in short: BAM. These days BAM is a very hot topic in the world. Every week the author receives some email messages about a conference somewhere in the world about BAM. What is BAM and when did it start? BAM was founded at a leadership meeting in 1999 in Oxford, England. ${ }^{31}$ It was developed as a solution to find more possibilities for missions. Yet if we look back in history, we can see BAM was not founded in 1999, but already existed in the past. Trade routes to China ensured that the Gospel was taken to other parts of the word outside the south of Europe and Israel. One of the most famous missionaries was William Carey, who worked as manager in an Indigo plant ${ }^{32}$. Indigo is an important pigment that is extracted from the Indigofera plant. Besides working as a manager, William Carey had a desire to bring the Gospel. Even in Paul's ministry we can see the ultimate example of how business activities can support a mission-trip. We can read this in the book of Acts, where Paul works every day as a tent maker. ${ }^{33}$ There are about 7 stages of BAM, all described in the book Bisnis Sebagai Sebuah Misi [Business as a Mission]. ${ }^{34}$

${ }^{31}$ P. Dekker, Bisnis Sebagai Sebuah Misi (Makassar: Sekolah Tinggi Theologia Jaffray, 2019), 46

32 Dekker, Bisnis Sebagai Sebuah Misi, 46.

${ }^{33}$ Russell , 91.

${ }^{34}$ Dekker, 49. 
Nevertheless, the author wants to give a caution about the use of BAM. BAM is not a method to move a business to a country where the costs of leading a business are much cheaper compared to the western world. In Europe the author joined some meetings with BAM managers. One was owner of a huge plant in the Netherlands that makes cheese. He wanted to move to the Ukraine.

This was a BAM project, he said:" The plant in the Netherlands would be closed. I will offer a lot of work options for the people in Ukraine." He said: "My mission is to offer the people in the Ukraine better living conditions, a higher than average wage and to help the country. We will start every working day with prayer". In the opinion of the author, this story is interesting for the people in the Ukraine but has nearly nothing to do with BAM. A lot of a big part of moving his business was based on the "B" from BAM, but it is hard to find the "M" for mission in this example. Besides that, the plant in the Netherlands will be closed and all workers will be fired. Is this a Christian way of doing business? In this story the money aspect is very important because the income of people in Ukraine is only $15 \%$ of that of the people in the Netherlands. His plant will make a lot more profit by moving and changing his workers for cheaper workers. The author cannot imagine that the Oxford group devised BAM for this kind of activity. On the other hand, BAM means setting up a real business that makes profit and also focuses on the mission field by reaching out to locals with the Gospel. BAM is a word with is a link between the B from Business and the $\mathrm{M}$ from Mission. Without the $\mathrm{B}$, there is no mission, without the $\mathrm{M}$ there is no business. A business cannot survive without profit. Profit is a good aim, every business needs profit, but there are limits on making profit. What will the business do with the profit? is this to bless the shareholders? Or will the profit work to get more market volume and a much larger company? Making profit is necessary for BAM. The profit can bless the mission. In the author's opinion, only the investment can flow back to the shareholders, without or only with low interest. Does BAM give more opportunities for mission? Yes, that is the author's deepest belief, but it is very important to work this out in a proper way, set it on paper and develop a model which is useful for the Indonesian market. 
Table 1. Step by step workplan ${ }^{35}$

\begin{tabular}{|c|c|}
\hline Step & Questions \\
\hline $\begin{array}{l}\text { Step l: Try to map } \\
\text { the area of focus }\end{array}$ & $\begin{array}{l}\text { - On which area will you focus? } \\
\text { - What local language do they speak? } \\
\text { - How can we find out which cultural things } \\
\text { are very important? } \\
\text { - Are there active churches or mission } \\
\text { organizations? } \\
\text { - Is there Christian education? } \\
\text { - Which population groups are living in this } \\
\text { area? } \\
\text { - How many people are not yet reached with } \\
\text { the Gospel? } \\
\text { - What is the main source of income? } \\
\text { - Which products or commodities are } \\
\text { available in this area? } \\
\text { - Are there possibilities to create a different } \\
\text { source of income? } \\
\text { - How can we setup a safe base from where } \\
\text { you can evangelize? } \\
\text { - How can we find financial support to start } \\
\text { the plan? } \\
\text { - With which church denomination do we } \\
\text { want to work with? } \\
\text { - Do we want to work together with a } \\
\text { Theological School and how can that be } \\
\text { arranged? } \\
\text { - The safest way to start is by setting up a } \\
\text { foundation social. How to arrange that? } \\
\text { - Try to find a couple who wants to be } \\
\text { responsible for the daily activities and to } \\
\text { live there. } \\
\text { - Pray and ask prayer from a group of people } \\
\text { with whom you are close, ask them to pray } \\
\text { for the mission on a daily base. }\end{array}$ \\
\hline & $\begin{array}{l}\text { - Form a team around you and start } \\
\text { brainstorming sessions, explore the area } \\
\text { and try to find out as much information as }\end{array}$ \\
\hline
\end{tabular}

${ }^{35}$ Inspired by S. H. Taylor, Global Mission Handbook (Illinois, USA: IVP Books, 2009), 112-113, 172-173. 
Step 2: Go out and investigate possible.

- Investigate anonymously the area where you want to work and eat or drink something in a simple restaurant.

- Try to find people in this area who can help and have a lot of connections in this area. Bentor or Ojek drivers have a lot of entrances because they know a lot of people. Bentor and Ojek is a cheap way of transportation in cities setup by locals.

- Try to discover other Christians in your area and make connections to work together.

- Think about starting a small business which adds value to this area. Use local products!

- Think about sales channels, where are possible outlets to sell your products?

- Search for others in Indonesia who are doing the same thing and start working together.

- Put all findings on paper and begin with all formalities like the permission to start a business.

- Be honest and do not join the system of corruption. It is better to wait till the right time instead of paying corruption money.

- Find moral support, some people can see more from God's perspective and are willing to voice their encouragement for the risky exploits for ministering in some "hard" areas.

- Look for logistics support, what will we sell or produce? How to find customers.

- Every mission needs prayer support; this is of the first importance. It is not asking God to do something He is unwilling to do; it is integrating with God's plan with the world?

- Find a place to rent for a year and start a

Step 3: Start small business.

- Try to connect with the locals by talking, 


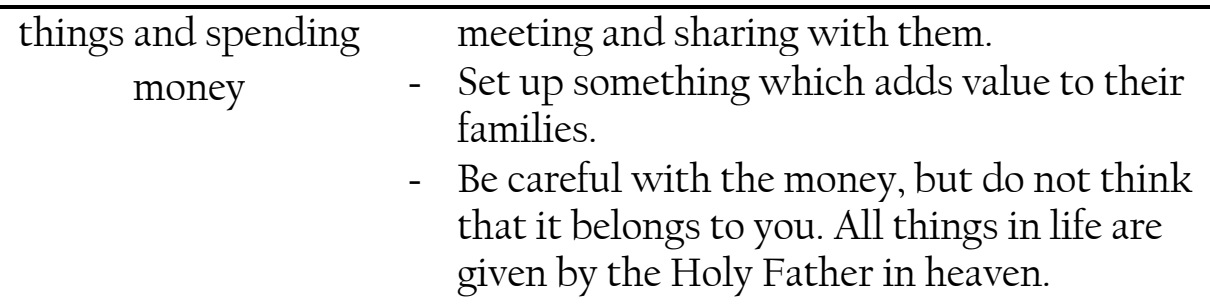

\section{Biblical Substantiation of Entrepreneurship}

Gandhi and Riana said that social entrepreneurship is a crucial element in the worldwide discussion, ${ }^{36}$ but is there a correlation between Entrepreneurship and the Bible? Yes, there are a lot of examples of people and verses in the Old Testament that we can describe as "Entrepreneur focused". There is a lot of business going on in the Old Testament.

Read the stories of Abraham, Moses, Job, David and Salomon. A lot of Bible verses are talking about tips for doing business. The following is a list of some of the verses:

- Proverbs 23:4 "Do not wear yourself out to get rich; have the wisdom to show restraint."

- Proverbs 20:4 "A sluggard does not plow in season; so, at harvest time he looks but finds nothing."

- Psalms 127:2 "In vain you rise early and stay up late, toiling for food to eat-for he grants sleep to those he loves."

- Proverbs 4:7 "Wisdom is supreme; therefore, get wisdom. Though it cost all you have, get understanding."

- Proverbs 21:5 "In the paths of the wicked lie thorns and snares, but he who guards his soul stays far from him."

- Exodus 35:35 "He has filled them with skill to do all kinds of work as craftsmen, designers, embroiderers in blue, purple and scarlet yarn and fine linen, and weavers- all of them master craftsmen and designers".

If we read the last verse from this list, we can see how a creative God created humans, and a wonderful summary of the many talents God used to make the Ark of the Covenant. This is a clear relation between Entrepreneurship and working in and for the Kingdom of God. The

${ }^{36}$ Tanvi Gandhi and Rishav Raina, "Social Entrepreneurship: The Need, Relevance, Facets and Constraints," Journal of Global Entrepreneurship Research 8, no. 9 (2018): 1, https://doi.org/10.1186/s40497-018-0094-6. 
church, however, needs to consider this: everything stands or falls with the plan. Starting business and/or mission activities together is something that will probably not survive without thinking and writing a business as mission plan. Like Proverbs 15:22 says: "Plans fail for lack of counsel, but with many advisers they succeed."

Believers should start discussions with each other and make sure to think about all the positive and negative sides of a plan. What has to happen for plans to succeed? What are the obstacles and who can help the church by setting up activities? It is impossible to do things on one's own, people need a team which supports, helps, prays and will be there when needed. The example of Moses from Exodus 18: 1-21 shows these principles. In this passage Moses is admonished by his father-in-law Jethro because Moses wants to do everything on his own. Nobody can sustain this, and people around you will be hurt by doing everything on your own. The hours in a day are limited, and you cannot work 24 hours a day. Jethro advices Moses to look for people who are wise and can lead. The starting point: engage in discussion with others, with God involved. Moses was always very busy. That is not what God wants from believers. A lot of businessmen have the same problem: They are working day and night. This is very sad for their family and people around them because there is no time for them. This is a very good reason to accept advice from other people. This is also important in the church. Pastors need to lead, but they need to not overwork themselves. It is important in the church to build a team around the pastor, a team full of faith, that meets on regularly basis and receives the input from others on the team. Try to think about the question: "How can we reach out to the people around us, who have not heard of Jesus?" In the New Testament we can find some advice about doing Entrepreneurship:

- Colossians 3:23-24 "Whatever you do, work at it with all your heart, as working for the Lord, not for men, since you know that you will receive an inheritance from the Lord as a reward. It is the Lord Christ you are serving."

- Matthew 7:12 "So in everything, do to others what you would have them to do to you, for this sums up the Law and the Prophets".

- Mark 8:36 "What good is it for a man to gain the whole world, yet forfeit his soul?" 
In the Indonesia church the leading opinion is that business and the church are polar opposites. Doing business is something that belongs to the devil (money), and that doesn't fit a spiritual leader of a community such as the church. To be clear, Jesus was not very mild towards the traders in the temple. As we read the passage in Matthew 21:12-13: "Jesus entered the temple area and drove out all who are buying and selling there. He overturned the tables of the money changers and the benches of those selling doves. "It is written", he said to them, my house will be called a house of prayer, but you are making it a 'den of robbers"'.

What does this mean? What was the reason for doing this in this way? Was Jesus against all kinds of trading? The answer is very clear: No, Jesus had no problem with doing business or trading, but Jesus had a great problem with the way the traders were doing trading in the temple. They were trading not for building the Kingdom of God, but for their own welfare and wealth. The traders used the Jewish religion to make themselves richer. They provide the offerings, the animals that were necessary for the offering services. It was also very clear; the traders did not offer the animals for the lowest possible price. They made a lot of profit. For the most beautiful animals they asked prices beyond everyone's reach. We can see this also in Toraja (Sulawesi), where for funeral ceremonies the most expensive animals are slaughtered. Very beautiful animals cost more than a new car. It is big business for the traders, they make a lot of profit. Profit is ok, every business need this, but is this what God supposed us to do? So, it is also a warning for the readers, when the $\mathrm{B}$ from business is much more important in comparison with the $\mathrm{M}$ from mission things will go wrong in the Kingdom of God.

When entrepreneurship is properly handled is also fits the church and it can give the church many more opportunities to reach outside the church. The most important rule is "entrepreneurship cannot be for the profit and the personal gain of the leading people of the church". Paul never thought to go to the market every day to become a rich person, but it was necessary for his personal living and to buy food and pay for living costs. This is the real principle of doing BAM, it can never be used as reason to make a business much larger and more profitable but is must have the goal to spend the profit for mission. 


\section{Conclusion and Recommendation}

To gain entrance into not yet reached areas you need Entrepreneurship. For selecting and finding these areas usable data is the school system. The author's plan to start a small plant in a village without Christians education seems workable. People in that village are enthusiastic that Christians stretch their arms to that part of the inhabitants that live in poverty. This is in contrast with the community of believers around them, who invest in new huge mosques. There is a lot of physical poverty in this areas, lack of income, lack of work possibilities, lack of good education, and a weak system of healthcare, but there is also spiritual poverty because the villagers do not know who Jesus is. It is striking that people never ask money. By reaching out to these peoples a lot of new contacts developed. There are many people who want to help us from the local villages. These people start thinking about what is necessary, offer a portion of their income to the people who are very poor, and start helping out the mission to alleviate the suffering of the people around them. Through these contacts arise a lot of conversations about "belief". Why will the author, as Christian, support our community? There are Christian students doing their internship together with the locals, and this has developed a lot of good relationships. There is respect and honor in this area for the work Christians are doing. It is no problem for the locals that people with a different faith focus on these areas. The biggest danger is not from the locals, but from local officials and the people outside these small villages. They visit the village from time to time and start preaching about the danger from other faiths. To start a church in these areas is a process which takes many, many years, even if the Indonesian law allows building churches when you have enough people who wants to sign for starting a church. The local authorities have a lot of influence and fully protect their own beliefs. A lot of locals are interested in the Christian faith or in Christianity, but to take the necessary steps to change from Islam to Christianity is complicated by the major influence of the community. One of the hardest things is that people in these families live in large family groups. You have to follow the beliefs of the family. When you decide to change to the Christian faith, the family will reject you. Some years ago, they even killed people who changed their faith and became Christians. At this moment it looks like God is opening the way 
in these areas. Praise God, he is involved! The way is open in Indonesia to show the people that there is only one way which saves: the road to the cross of Jesus Christ. Only through his suffering, death and resurrection does He give us the grace we all need in our lives.

Recommendations, the main focus is on Gereja Kemah Injil Indonesia, but these recommendations are also useful for other church denominations:

1. Everything starts with praying, so organize prayer meetings to ask God what He wants.

2. It would be good for Gereja Kemah Injil Indonesia to start a commission that chooses certain areas where they want to focus evangelism over the next five years. The commission that will manage this should work in partnership with The Christian \& Missionary Alliance, YKPI (Yayasan Kemah Peduli Indonesia). They should try to find financial support to send out these educated workers (all Indonesians) for that period.

3. The commission will support these workers for three years from the finances pooled together by the Gereja Kemah Injil Indonesia (see point 5). After that they need to raise their own support by their own business.

4. Work together with Christian businessmen who want to be involved with missions. Think of setting up an association of Christian businessmen. Let them think how to start a small business, give support and make it possible to setup small businesses in the areas chosen in point 1.

5. Try to convince the Theological schools from Gereja Kemah Injil Indonesia that it is important to go on a mission trip to a not yet reached area. Think together about the possibilities.

6. Offer education to couples who are interested doing a combination of Entrepreneurship and missions.

7. Make a rule for all Gereja Kemah Injil Indonesia-churches to support this with $2 \%$ of their yearly income. From this support it is possible to setup all activities. This $2 \%$ is only reserved for missions and funding trips to areas which are not yet reached.

8. The commission will offer workers or couples a contract for a period of three years with a restriction to evaluate year by year. After three years they have to support themselves. If there is not yet fruit from the mission or they do not seem to fit, either party has the option to end the contract at the time of the yearly evaluation. The commission helps to think about a workable plan and to setup a business which has a legal status in this area. The commission can support some inventory; this inventory is loaned out by the commission and not the property of the worker. 
9. Setup all activities under the umbrella of Yayasan Kemah Peduli Indonesia or another Yayasan that has outreach as one of its goals. Both of these options have a social component and fit the idea of doing business to reach the important majority.

\section{Bibliography}

"Indonesia Earthquake: Hundreds Dead in Palu Quake and Tsunami." https:/www.bbc.com/news/world-asia-45683630.

"Portal Informasi Indonesia: Profil - Agama." https://www.indonesia.go.id/profil/agama.

"Publikasi Statistik - SD." http://publikasi.data.kemdikbud.go.id/uploadDir/isi_3939CAB97519-4743-817D-451543C7CFBB_.pdf.

"Publikasi Statistik - SMA." http://publikasi.data.kemdikbud.go.id/uploadDir/isi_AF06EEA9768D-4A19-B2C9-0C69E973DFBF_.pdf.

"Publikasi Statistik - SMK." http://publikasi.data.kemdikbud.go.id/uploadDir/isi_02552295057B-4347-BCB3-71A2DIE2AEEC_.pdf.

"Publikasi Statistik - SMP." http://publikasi.data.kemdikbud.go.id/uploadDir/isi_2D2BE4A71490-4240-8A30-1FCCC29696B0_.pdf.

"Publikasi Statistik." http://publikasi.data.kemdikbud.go.id/index.php?thn=2019\&sek_i $\mathrm{d}=\&$ \&pid=\&pageNum=2.

"Salarissen En Minimumloon In Indonesië (2019)." https://indearchipel.com/2018/12/07/minimumloon-indonesie2019/.

"Your Dictionary." https://www.yourdictionary.com/.

Austin, James, Howard Stevenson, and Jane Wei-Skillern. "Social and Commercial Entrepreneurship: Same, Different or Both?" SAGE Journal: Entrepreneurship Theory and Practice 30, no. 1 (2006): 1-22. https://doi.org/10.1111/j.1540-6520.2006.00107.x.

Bailey, S. Biblical Wholism. Colorado Springs: Cama Services, 2019.

Bryman, Alan. Social Research Methods. $4^{\text {th }}$ edition. New York: Oxford University Press, 2012.

Certo, S. Trevsi, and Toyah Miller. "Social Entrepreneurship: Key Issues and Concepts." Business Horizons 51 (2008): 267-271. https://doi.org/10.1016/j.bushor.2008.02.009. 
Dagblad, R. "Reformatorisch Dagblad.” https://www.rd.nl/kerkreligie/indonesië-sluit-twee-kerken-1.1587326.

Dekker, P. Bisnis Sebagai Sebuah Misi. Makassar: Sekolah Tinggi Theologia Jaffray, 2019.

Dodd, Sarah Drakopoulou, and George Gotsis. "The Interrelationships between Entrepreneurship and Religion." The International Journal of Entrepreneurship and Innovation 8, no. 2 (2007): 93-104. https://doi.org/10.5367/000000007780808066.

Fauzia, A. "Islamic Philanthropy in Indonesia: Modernization, Islamization, and Social Justice." Austrian Journal of South-East Asian Studies 10, no. 2 (2017): 223-236. https://doi.org/10.14764/10.ASEAS2017.2-6.

Gandhi, Tanvi, and Rishav Raina. "Social Entrepreneurship: The Need, Relevance, Facets and Constraints." Journal of Global Entrepreneurship Research 8, no. 9 (2018): 1-13. https://doi.org/10.1186/s40497-0180094-6.

Kushidayati, Lina. "The Development of Islamic Law in Indonesia." शIJIS: Qudus International Journal of Islamic Studies 1, no. 2 (2013): 163-180. https://journal.iainkudus.ac.id/index.php/QIJIS/article/view/185/19 2.

Mair, J. R. Social Entrepreneurship. Basingstoke: Palgrave Macmillan, 2006. Marshall, Jerry. "Is Rural Enterprise God's Business?" Rural Theology 14, no. 2 (November 2016): 82-91. https://doi.org/10.1080/14704994.2016.1234852.

Marzocchi, Chiara, Fumi Kitagawa, and Mabel Sanchez-Barrioluengo. "Evolving Missions and University Entrepreneurship: Academic Spin-Off and Graduate Start-ups in the Entrepreneurial Society." The Journal of Technology Transfer 44 (2019): 167-188. https://ink.springer.com/content/pdf/10.1007/s10961-017-96193.pdf.

Munoz, Pablo, and Jonathan Kimmit. "Social Mission as Competitive Advantage: A Configurational Analysis of the Strategic Condition of Social Entrepreneurship." Journal of Business Research 101(2019): 426-432. https://doi.org/10.1016/j.jbusres.2019.02.004.

Practitioners. Hands. Colorado Springs, USA: CAMA Services, 2019. Ricklefs, M. Islamisation and Its Opponents in Java: A Political, Social, Cultural and Religious History, c. 1930 to the Present. Singapore: National University of Singapore Press, 2012.

Russell, M. L. The Missional Entrepreneur. Birmingham, Alabama, USA: New Hope Publishers, 2010. 
Taylor, S. H. Global Mission Handbook. Illinois, USA: IVP Books, 2009.

Ward, P. Liquid Ecclesiology: The Gospel And The Church. Leiden: Brill, 2017.

Zahra, Shaker A. "International Entrepreneurship in the Post Covid World." Journal of World Business (2020): 1-7.

https://doi.org/10.1016/j.jwb.2020.101143. 